\title{
Reception of the First Translation of Günter Grass's Die Blechtrommel in the Major Finnish Press
}

\author{
Christoph Parry
}

\begin{abstract}
In diesem Beitraggeht es um die unmittelbaren Reaktionen derfinnischen Zeitungskritik auf die Veröffentlichung der ersten finnischsprachigen Übersetzung der Blechtrommel im Jahre 1961. Finnland war in den ersten Jahrzehnten nach dem Zweiten Weltkrieg ziemlich isoliert und weitgehend mit sich selbst und dem schwierigen Verhältnis zum sowjetischen Nachbarstaat beschäftigt. Die schweren Gegensätze, die das Land in den ersten Jahrzehnten der Unabhängigkeit politisch belastet hatten, verlagerten sich in der frühen Nachkriegszeit aus Rücksicht auf die sensible außenpolitische Lage auf das kulturelle Feld, wo sie sich in einer Reihe von heftigen Literaturstreiten bemerkbar machten.
\end{abstract}

Bei der Rezeption der in West-Deutschland kontrovers aufgenommenen Blechtrommel zeigt sich allerdings, dass sich die Polarisierung im finnischen kulturellen Feld nicht auf die Aufnahme importierter Werke erstreckte. Angefangen mit der großen Rezension von Pentti Saarikoski, im Literaturjournal Parnasso tritt die stereotype Vorstellung von der allgemeinen Schwerfälligkeit deutscher Romane regelmäßig in Erscheinung, wobei oft entschuldigend auf die angeblich polnische Herkunft des Autors hingewiesen wird. Die Rezensenten übersehen dabei systematisch die bewusste Ambiguität Oskars, der mit seinen zwei Vätern jede nationale Zuordnung verweigert. Mit Hinweisen auf Rabelais, Cervantes, Gogol und Joyce wird der Roman in den abendländischen Kanon eingereiht.

Dass importierte Werke mit anderem Maß als einheimische Neuerscheinungen gemessen werden, fällt insbesondere anhand der Rezension von Toini Havu in der führenden Tageszeitung Helsingin Sanomat auf. Die Rezensentin, die sieben Jahre früher den Feldzug gegen Finnlands Nachkriegsklassiker, Väinö Linnas Der unbekannte Soldat, eingeleitet hatte, betrachtet nun Grass' gewiss nicht weniger autoritätskritischen Roman mit deutlichem Wohlwollen. Während die finnische Gegenwartsliteratur von den Rezensenten eindeutig referentiell im Kontext außerliterarischer Fragestellungen gelesen wird, wird Die Blechtrommel in eine ehrenwerte weltliterarische Ahnenreihe eingebettet und als zeitloser Schelmenroman gelesen.

(C) CHRISTOPH PARRY, 2016 | DOI 10.1163/9789004291898_011

This is an open access chapter distributed under the terms of the CC-BY-NC License. 
As is the case in several other European languages Die Blechtrommel has twice been translated into Finnish. The first translation of the novel by Aarno Peromies appeared in 1961, shortly after the novel's first publication in Germany, when it was regarded as a daring piece of avant-garde writing; the second, by Oili Suominen in 2009, was part of the international retranslation project (discussed elsewhere in this book). By this time Die Blechtrommel had already achieved the status of a classic. In fact the latter project can be seen as a symptom of the novel's ultimate consecration. Between the two translations the novel was rereleased in Finland a number of times and brought to the public's attention through the film adaptation by Volker Schlöndorff, shown both in Finnish cinemas and on television, and by a Finnish dramatisation for the stage by Seppo Parkkinen. This stage adaptation was first produced in 2008, shortly before the publication of the new translation. While evidently influenced by Schlöndorff's film, Parkkinen's script moves closer to the original by including material from the third part of the novel which deals with Oskar's life in the post-war period and reintroducing the narrative frame of Oskar recounting his life in the psychiatric ward.

In the half century that elapsed between the two translations Finnish society changed dramatically. In 1961 Finland was still a relatively poor country in the throes of a belated industrialisation and urbanisation process promoted by the need to meet Soviet demands for reparation payments and at the same time beginning to supply its richer Swedish neighbour with migrant labour. Apart from close contacts with Sweden Finnish society was internationally fairly isolated. A national broadcasting service providing a single television channel and two radio channels in Finnish and one in Swedish, kept people informed of what went on in the outside world. In addition there was, however, an extensive and well established press with a broad base in society. By 2009 , the year of the second translation, Finland was already in transition to a postindustrial society, fully integrated in the European Union and exposed to the influx of the global media. The conditions for the reception of contemporary foreign literature have consequently changed, but whether the changed conditions are directly reflected in the critical reception in book reviews is a question that will be addressed in this and the following chapter.

In the present chapter I shall look at how the first translation of the novel was presented to the reading public by reviewers in the major Finnish journals and newspapers of the time, taking into account some of the cultural and historical peculiarities of the Finnish situation. An important factor that could be expected to have some influence on critical reception practice in Finland is the relative youth of the Finnish nation state: this may have had an effect on the autonomy of its cultural field. A further reason for paying close attention to 
historical issues arises from the novel itself. As many generations of readers have come to accept, one of the most important features of Die Blechtrommel is its sharply focussed but decentralised view of 2oth century European history. With the bulk of the novel set in the multicultural city of Danzig and its critical stance towards the national aspirations of both the German and, to a lesser extent, the Polish communities in the city, Die Blechtrommel is an obvious example of a European, rather than national, novel. This being the case, the study of various national receptions of the novel cannot avoid dealing with the issue of how the historical events of the 2oth century have been represented in the social imaginaries of the various countries involved.

\section{Origins of the Cultural Field in Finland}

Finland, which only became an independent nation in 1917, belongs geographically and historically to the European periphery. To understand Finnish reactions to Grass's novel it seems appropriate to indulge in a brief excursus into Finnish history, that is, the grand narrative of Finland's progress from a Grand Duchy within the Russian Empire to its present role as an active sovereign participant in the European integration process. In fact, the establishment of the Grand Duchy itself in 1809 when Sweden's former Eastern provinces were integrated into the Russian empire could be regarded as the first major step towards the establishment of modern Finnish nationhood. ${ }^{1}$ This was the first time the whole of Finland, including the Eastern areas which had been joined to the Russian empire earlier, became united in a recognisable administrative unit. Within this new framework, and in the context of a Europe-wide fashion for romantic nationalism, awareness of national identity grew. Promotion and consolidation of the Finnish language was now actively pursued - not least by Swedish speaking intellectuals.

Prior to Russian rule the small urban and academic elite had generally been Swedish speaking while the majority of the peasant population in the interior had spoken Finnish. Until the 19th century the use of Finnish as a written language had been largely restricted to religious works. Swedish was the language of administration and, next to Latin, the language of education. Severance from Sweden in the period of upsurging romanticism in the early 19th century provided an incentive for many academics to take an interest in the mores and language of their fellow countrymen. The founding of the Finnish Literature Society in 1831 is recognised as a milestone in the promotion

$1 \quad$ Klinge (2011) 15. 
of a Finnish national identity, as was the work of Elias Lönnrot in collecting the legends of the Kalevala and compiling the national epic. During the second half of the 19th century the use of Finnish gradually spread to education and administration.

The late development of the national language and the continued strong presence of Swedish as a minority language have left their mark on the Finnish cultural field until the present day. This field is small, young and divided. On the one hand the institutions of cultural life such as professional theatre, publishers, journals and newspapers, are relatively young. Not untypically for emerging national cultures a small number of actors play multiple roles in the field. Writers are often reviewers, teachers are writers etc. Limited opportunities for full time professional engagement within the field necessarily restrict its autonomy. On the other hand the institutions are partially duplicated with parallel institutions serving the Swedish speaking minority and often pursuing different interests. This division particularly affects reading habits and the import and translation of literature, since the Swedish language market is largely served by publishers from Sweden. ${ }^{2}$ The cultural affiliation of a significant minority of the educated public with a neighbouring country caused much friction in the early decades of independence and some suspicion remains even today in spite of the unquestioned predominance of Finnish as the first national language.

A further special feature that needs to be taken into account when considering the Finnish reception of a German novel is the traditional position of German culture in Finland. As is the case in Scandinavia generally, for geographical reasons cultural exchange with the rest of Europe largely passed through Germany until well into the 2oth century. The most apparent and traditionally significant German influence has however been through the Reformation. The Lutheran Church has traditionally had a much stronger hold on society in Scandinavia than in Germany itself. German influence in Finland was also strong in the nineteenth century in academic circles particularly in the development of academic institutions.

The presumed familiarity with Germany may have been illusory even at the beginning of the 2oth century. Certainly an image of Germany moulded by Lutheranism and idealist philosophy could hardly prepare an audience for a work like Grass's Die Blechtrommel with its multicultural and Catholic setting. In fact cultural relations between Finland and Germany in the first half of the

2 A Swedish translation (by Nils Holmberg) was published by Bonnier in Stockholm in 1961, the same year as Peromies's Finnish translation. For the purpose of the present study, only the reception of the Finnish translation in the Finnish language press will be discussed. 
twentieth century were marked by not only by a protestant perspective but also by a conspicuous right wing political bias. This was a consequence of events in connection with World War I and Finland's achievement of full independence. As part of its offensive against imperial Russia during the Great War, Germany had armed and trained Finnish nationalist partisans whom they continued to support even after Russia had withdrawn from the war. Thus when a brutal civil war broke out in the first months of Finnish independence a German intervention force helped secure the white (bourgeois) ${ }^{3}$ victory. The ensuing conspicuous germanophilia among the right wing bourgeoisie in the 1920s, in academic circles in particular, came to be associated with anti-Bolshevism and estranged the defeated socialists and labour movement. ${ }^{4}$ While German classics were being retrieved for a wider Finnish reading public, contemporary developments in German culture and modernist works in particular were largely neglected, except in relatively small socialist circles such as the workers' theatre movement. The polarisation of Finnish society continued until hostilities with the Soviet Union broke out in 1939.

\section{Finnish Literature and Society in the 1950 s and Early 1960 s}

Like Germany, Finland was among the losers of World War II, but unlike Germany Finland retained de jure all the attributes of a sovereign nation while de facto being obliged to respect the interests of its Soviet neighbour. Over the four decades of the Cold War Finland succeeded in avoiding the fate of the Soviet Union's Eastern European satellites. Finland retained a freely elected parliament representing a broad spectrum of political opinion, an almost completely free press etc. But the close proximity of the former enemy and the Baltic neighbours' experience of occupation cast a permanent shadow. To avoid provoking the victorious neighbour cautious pragmatism was called for. The need for a politics of conciliation also affected the political climate in the interior, effectively putting an end to the open antagonism between the right wing bourgeoisie and the working class movement that had prevailed in the 1920 and 1930s. However class antagonism did not disappear altogether, but it shifted from the political to the cultural arena.

The post-war decades saw a number of controversies over art and literature. In spite of a short interregnum in the immediate aftermath of the war when

3 Similar to the conflicts in other regions of the former Russian empire the parties were labelled 'red' and 'white'.

4 For a discussion of right wing Finnish germanophilia see Parry (2011) 292-296. 
left wing intellectuals briefly occupied prominent positions in cultural life, ${ }^{5} \mathrm{a}$ gradual return to the old status quo took place and conservative academics resumed their influence on cultural matters. And if debate was somewhat subdued, at least as regards Finland's foreign political interests, embittered struggles took place in the cultural sphere. No doubt the strong affiliations of individual newspapers to certain political parties - a characteristic of the Finnish press in the 1950s and '6os resembling the verzuiling in the Netherlands but without the confessional aspect ${ }^{6}$ - may have played a role in aggravating polemics.

One topic that repeatedly gave rise to heated debate was the interpretation of the war years themselves. Since much of Die Blechtrommel deals with the same period, Finnish controversies on the subject might be expected to have had some effect on the way the novel was received in the Finnish press. For a long time the accepted Finnish interpretation of events in the war diverged noticeably from that which was common elsewhere. It is only recently, in fact since the fall of the Soviet Union, that Finnish historians admit that Finland played a part in World War II at all. Accepted practice was to speak of two separate wars between Finland and the Soviet Union concurrently with World War II and a brief epilogue when Finland, after ceasing hostilities with the Soviet Union, was required to forcibly drive its former ally Germany out of the country.

This is a convenient way of downplaying the role of Finland's military cooperation with Germany in the years 1941-1944 but it also reflects the fact that Finland was indeed left on its own when attacked by the Soviet Union in the Winter War of 1939-40. The Winter War itself has subsequently become something of a foundational myth for the Finnish republic, in that it was seen to have generated a sense of national unity that was severely impaired by memory of the brutal civil war of 1918 and its aftermath. A number of novels critical of Finland's wartime policy, especially that of the second phase when Finland cooperated with Germany, were published. These were regularly condemned by conservative politicians, army veterans and representatives of the Church. Even Tuntematon sotilas (The Unknown Soldier) by Väinö Linna, which was filmed in the first year after publication and quickly became canonised as a

5 A notable example is Hella Wuolijoki, internationally known for her collaboration with Bertolt Brecht on the play Herr Puntila und sein Knecht Matti who, after being interned as a traitor during the war, became director of the Finnish broadcasting company YLE from 1945 to 1949.

6 The division still reflected class antagonisms of the civil war, the left wing press however tending to be more secular. 
classic of Finnish literature, ${ }^{7}$ was strongly rebuked in the press for its poor view of Finnish wartime morale and its disrespectful attitude to military leadership. Similar charges were brought against Paavo Rintala's novel Sissiluutnanti [The Guerilla Lieutenant] in 1963 which was said among other things to dishonour the women's auxiliary 'Lotta Svärd' movement.

The war was not the only sensitive issue to provoke public debate. In 1965 the writer Hannu Salama was convicted for blasphemy for a speech made by one character in his novel Junhannustanssit [A Midsummer Night's Dance]. A further case of blasphemy made the headlines in 1969 when artist Harro Koskinen exhibited a work depicting the crucifixion of a pig. Again the artist was fined and the work was censored.

All this reveals a considerable potential for conflict in the cultural life of Finland when Grass's Die Blechtrommel, a novel hardly respectful of authority and by no means free from passages which could be seen as blasphemous, was first published in Finnish. But was foreign literature susceptible to the same kind of reception? In this connection two closely related questions need to be asked when examining the early reviews of the novel: firstly, to what extent did reviewers mention the controversies surrounding the original publication of the novel in Germany and, secondly, did they draw any connections between the controversial potential of the novel and the contemporary controversies in Finnish cultural life?

\section{Early Press Reviews of Die Blechtrommel in Aarno Peromies's Translation}

At this point we can take a closer look at the early reviews of Die Blechtrommel in the Finnish press. Reviews and short news items appeared in newspapers and in a variety of diverse magazines and weeklies, ranging from the weekly bulletin of the diocese of Helsinki through various consumer magazines issued by retail chains. Such publications, aimed at a general and unprofiled readership, should not be underestimated in a small and relatively homogenous society. ${ }^{8}$ A short note can also be found in an organ for Finnish librarians, with

7 The first film version, directed by Edvin Laine (1955) is now shown on Finnish television every year on independence day.

8 According to Pekka Tarkka (1966) 83, the campaign against Paavo Rintala's novel Sissiluutnanti was triggered by an article in yhteishyvä published by the soK cooperative group. 
the aim of guiding purchasing decisions. ${ }^{9}$ However, I shall concentrate mainly on early reviews in major daily newspapers. ${ }^{10}$

The earliest review to appear was, however, in the literary journal Parnasso which was probably read by the critics, if not by the newspaper audiences at large. Written by prominent poet and translator Pentti Saarikoski, a young revolutionary neo-modernist and enfant terrible of 196os Finnish literature, this enthusiastic and somewhat unconventional review deserves particular attention, because it seems to set the tone for many of the reviews to follow. ${ }^{11}$ Saarikoski opens his review by comparing the novel with Väinö Linna's contemporary epic trilogy Tä̈̈llä Pohjantähden alla [Under the North Star] and follows this up with a qualitative judgement which is at the same time flattering and flippant: "This is Germany's Under the North Star, a reckoning with the events of the twentieth century and in the opinion of many critics one of the best German novels ever written - after all, the author is Polish." What Saarikoski here quite obviously means as a joke at the expense of German novels in general will later be taken up by many other reviewers, but without his implicit irony. In fact the first slightly inaccurate reference to Grass's ostensible Polish origins can already be found on the back cover of the first edition of Peromies's translation. A closer reading of the novel itself would reveal that Grass clearly differentiates between the Poles and the Kashubian ethnic minority to which his own mother, just like Oskar's, belonged.

Another feature of Saarikoski's review that was to be taken up by other reviewers is the question of genre. After citing, in apparent agreement, a lengthy passage from the beginning of the novel where Grass, or Oskar as narrator, expressly refuses to adhere to any particular genre conventions, Saarikoski somewhat reluctantly once more follows the publisher's lead on the back cover of the novel and places it into the neat genre compartment of the picaresque, which the subsequent reviewers are all too happy to adopt as the basis for their readings.

Saarikoski's central metaphor, which also forms the title of the review, is Cinerama. This is actually a misnomer. From his description it becomes apparent that he is referring to the short lived 'circlorama' or cinema in the round that was briefly fashionable in the early $1960 s$. Be that as it may, Saarikoski tries to convey the totalising effect of Grass's writing, which immerses the reader in the world of the novel. Unsurprisingly for the figurehead of Finland's belated

\footnotetext{
$9 \quad$ Kerttu Manninen (1962) 32.

10 The early reviews have previously been discussed in an unpublished Masters' thesis by Rolf Wilfinger (1993).

11 Saarikoski (1961). Translations of quotations from Finnish reviews by C. P.
} 
bohème Saarikoski evidently highly appreciates the rich and disorderly narrative texture of Grass's novel and compares it to Rabelais, Gogol and James Joyce's Ulysses. Attributing such a pedigree to Grass's work raises it onto the pinnacle of world literature. This effect is further emphasised when he compares the book with the work of Germany's previous internationally most established novelist, Thomas Mann, much to the detriment of the latter. Saarikoski asks if Die Blechtrommel is a new Ulysses or a successful parody of Thomas Mann's giant novels with their "endless regurgitation of the same images" and ends his discussion of the novel by calling Grass the ultimate novelist who has "laughed Thomas Mann out of the arena."

Most of the reviews follow Saarikoski in their positive assessment of the novel and this generally positive reaction is further emphasised by the range of references and comparisons with other well-known works. A small number of comparisons with Finnish literature are made. Saarikoski's comparison with Linna's epic of the 2oth Century is one. Suomen sosiaalidemokraatti, organ of the Social Democratic Party, refers to the Finnish novelist Volter Kilpi and to the popular Finnish humourist Veikko Huovinen, in order to give some impression of Grass's style. These references are basically an economical way of providing some kind of general orientation. Reference to contemporary German writing, mostly found in Toini Havu's article for Helsingin Sanomat, ${ }^{12}$ helps situate Grass in the context of German writing of the late '5os, an issue with which most of the reviewers do not concern themselves and with which they apparently do not expect much familiarity among their readers.

Most of the references, however, are to the major canon of European literature. Thomas Mann and Grimmelshausen are the two German authors mentioned who can be situated in this category. An obvious choice for mention in view of the general agreement on the picaresque nature of the novel is Cervantes, specifically mentioned in Aamulehti. ${ }^{13}$ Other canonical authors named or alluded to include Rabelais, Shakespeare, Swift, Defoe, Gogol, Dostoevsky, Joyce, Lagerqvist, Ionesco and Beckett. The most active name droppers were Saarikoski in Parnasso and Havu in Helsingin Sanomat. The purpose of these references is obviously qualifying rather than informational. As this venerable list reveals, Grass, for all the weaknesses in the organisation of his novel that his Finnish reviewers did not fail to mention, was accorded a seat on the Parnassus of European literature.

Raising Die Blechtrommel into the class of timeless classics was not without side effects. It effectively buffered the work against discussion in terms of

\footnotetext{
12 Havu (1961).

13 R-o S-lä (1961).
} 
contemporary public debate. This effect is enhanced by the fact that almost all reviewers discuss the novel in terms of the picaresque, as Saarikoski and the publisher before him had done. The Finnish term is 'Veijariromaani' which is a direct translation of the German 'Schelmenroman' where the typical hero is the Schelm, the joker, mischief maker or rogue: there is no exact equivalent in English. The term is used in Aamulehti, Helsingin Sanomat, Uusi Suomi, Kaleva and Vaasa. ${ }^{14}$

Mirjam Polkunen in Uusi Suomi discusses the matter at some length and expresses the opinion that Die Blechtrommel can indeed stand up to comparison with its classic predecessors. ${ }^{15}$ In Germany itself, she claims, you have to go as far back as Grimmelshausen's Simplicissimus to find a predecessor. A sharply contrasting novel is however to be found, in her opinion, quite close at hand, Böll's Billard um halbzehn. It would have been interesting to know what she means by this comment but unfortunately, perhaps due to lack of space, Polkunen does not further expound this opinion.

The reviewer in Tampere's Aamulehti sums up his presentation of the novel by saying of the author that he is 'Aika veijari!' [quite a rogue]. ${ }^{16}$ The reviewer in the leading northern Finnish daily newspaper Kaleva, writing under the pseudonym 'Seppä', takes a different line from most. ${ }^{17} \mathrm{He}$ explicitly refutes the adequacy of the 'picaresque' as a term to describe the novel, basing his argument not so much on the characteristics of the writing which in his view is often lewd or obscene, but on the implicit earnest undercurrent of the plot. The drastic plot where so many characters meet with an absurdly accidental end represents the tragic absurdity of the war itself and conveys a sinister undertone that, in the reviewer's opinion, no longer fits the attribute of the picaresque.

The review in Kaleva is also interesting in that it is constructed on an argument that makes explicit the stereotyped view of the German novel that was already apparent, but only implicitly, in Saarikoski's review in Parnasso: the impression that German novels tend to be particularly long and heavy-handed. 'Seppä' devotes quite a long section at the beginning of his review to an exposition of all that tends to be wrong with German novels: they are long, slow-going, and lacking in humour. The reviewer even goes so far as to attribute these features to the national character. Die Blechtrommel is of course also a very long novel but one which in the reviewer's view is not in the least

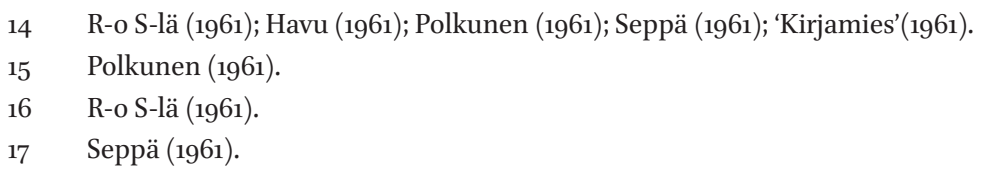


heavy-handed and certainly very much worth the effort of reading. He is however quick to attribute this unusual exception to Grass's origins as half Polish, repeating the inaccurate detail disseminated by almost all the reviewers.

By their insistence on pointing out the author's origins the reviewers reveal their own provinciality because they have obviously all missed an essential point that the novel makes, namely the ambivalence and ultimate irrelevance of national and ethnic origins in the first place. Instead of staring at the person of the author they might have paid closer attention to Oskar and his two presumed fathers. Two critics mention Oskar's doubt that Matzerath, his mother's husband, is in fact his father, but they overlook the subversive implications of this particular detail in the context of National Socialism and the nationalist ideology that gave birth to it. ${ }^{18}$ In the biggest wave of 'ethnic cleansing' that modern Europe has ever experienced and that ultimately destroyed the cosmopolitan basis of Danzig's society, Oskar is inherently ethnically unclean. So when the Finnish critics emphasise that this rich novel does not meet their expectations of what typical German novels are supposed to be like, and start speculating that this may be due to the Slavic origins of the author, they unwittingly fall precisely into the trap of ethnocentric petit bourgeois thinking that Grass satirises.

The reviews in the two major national daily newspapers, the conservative Uusi Suomi, organ of the National Coalition Party 'Kokoomus' and the more liberal Helsingin Sanomat go into more depth than most in discussing the novel in the context of contemporary West German literature. ${ }^{19}$ Both reviewers were prominent figures in Finnish cultural life of the time. Unlike most of the reviewers discussed here, Mirjam Polkunen, writing in Uusi Suomi, refers to the contemporary context of German literary life mentioning Gruppe 47 and, as mentioned above, Heinrich Böll's novel Billard um halbzehn, published in the same year. She sees Die Blechtrommel as evidence of a gradual recovery of German literary life. She calls its publication in Germany a sensation and describes its controversial reception there including a mention of the withholding of a major literary award. ${ }^{20}$ The Finnish publication is also in Polkunen's opinion a major event that can leave no-one cold.

But despite her evident familiarity with the contemporary German literary scene, even this reviewer resorts to the stereotypical view of German writing

\footnotetext{
18 A. I.-la (1961); R-o S-lä (1961).

19 Polkunen (1961); Havu (1961).

20 While she does not specifically mention the city of Bremen she is in fact referring to the Prize of that City which the city fathers refused to confer to Grass after he had already been selected.
} 
we come across often elsewhere. She too says that one would not expect such a novel to come from Germany and goes on to point out that there is a portion of Slavic Polish blood in the writer, from which she can therefore assume he has learned from Gogol and Dostoevsky. This is of course reviewers' rhetoric. There is no reason to assume that Polkunen any more than any of the other reviewers seriously believes in a causal relationship between Slavic blood and reading Dostoevsky!

Polkunen goes into some detail in describing the contents of the novel including Oskar's early adult life in Düsseldorf, before discussing aspects such as the symbolism of the novel. She compares Oskar with Selma Lagerkvist's dwarf, whose hunchback has given him a sharp but evil eye. But Oskar is much more ambivalent. "Oskar is an outsider and the centre, he is I and Oskar, the spectator and the object of view. By refusing to assimilate he remains in the middle. He is East and West, Rasputin and Goethe." This is a close and intelligent reading revealing the unique nature of Grass's shifting point of view. Polkunen deals also with other aspects of symbolism in the novel: Oskar's attempt to get the child Jesus to drum his message in the Danzig church; and the overwhelming wealth of sexual fantasies in the book, a feature best understood, in Polkunen's view, as a satire on Freudian psychoanalysis.

Helsingin Sanomat, Finland's biggest national newspaper, was relatively late reviewing the book. The review by Toini Havu is very enthusiastic and at the same time in its style and content somewhat idiosyncratic. ${ }^{21}$ More an essay than a review in the strictest sense this contribution presents both a personal reading of the novel and a polemical discussion of Finnish writing of the time.

Once more the picaresque novel is named as one model for the book, but the reviewer does not try to force it into a distinct category and emphasises that the book cannot be reduced to a single interpretation. In this late contribution the reviewer seems to assume that many of her readers already know something about the novel. Hence information about the content of the book is sparse and impressionistic rather than detailed, and there is no background information about the author except for the sentence in which he is first introduced (together with two other writers), with the standard characterisation as being Polish-German, born in Danzig and living in self chosen exile in Paris. The reviewer mentions the mixed reception of the novel in Germany but does not join its opponents. Instead she credits Die Blechtrommel as belonging to the "crème de la crème" of modernist writing.

Instead of a synopsis the reviewer takes up Grass's image of the drummer drumming out his story and chooses to describe the work in terms of music 
rather than conventional narrative. This unusual approach, revealing quite a degree of sensitivity towards Grass's aesthetic concept, is actually quite surprising in view of the reviewer's reputation in the domestic literary field.

Toini Havu, the reviewer, was a prominent critic in her time, renowned for her right wing politics and her condemnation of the more social critical strain in contemporary Finnish literature. In particular Havu is remembered for her condemnation of Väinö Linna's above mentioned novel Tuntematon sotilas [The Unknown Soldier] the book that was to become Finland's canonical work about World War II, thereby setting one of the more vicious historic controversies of Finnish literary life into motion. ${ }^{22}$ Linna's book takes the standpoint of the ordinary soldier who experiences fighting at the front as a pointless exercise. Havu's nationalist critique of Linna's work resembles the stance of Socialist Realism, despite coming from the opposite political direction, in that she misses positive attitudes among the characters and a sense of historical necessity in the author. Dealing with that novel in 1954, Havu demanded the inclusion of a historical perspective that would reveal to the readers the dimension that was not visible to the characters themselves. Linna's novel is indeed written in a conventionally realistic manner which is perhaps susceptible to a naïve critique of the characters' morals and attitudes in a way that Die Blechtrommel, narrated as it is from Oskar's eccentric perspective, is not. However despite the evident difference in style between the two books, it still seems a little surprising that the same critic who chided Linna for the disrespectful and unpatriotic attitude of his characters should write quite such a positive appraisal of Grass's novel. Whereas in 1954 Havu found the Finnish war novel with its conventional realistic writing deficient, in 1961 she seems to totally approve of Grass's approach. Not only that, but with an abstruse twist of argument she actually uses Grass and his German contemporaries as pawns in her own crusade against the younger generation of Finnish writers. Instead of the more conventional biographical opening, this review starts with a general discussion of post-war Germany's 'lost', or 'fatherless generation' and its approach to the recent past which, she claims, is an honest appraisal in complete contrast to the 'shameful' way young Finnish authors follow ideological fashions in dealing with their own country's recent past. In addition to Die Blechtrommel she mentions Heinrich Böll's Billard um halbzehn, Uwe Johnson's Mutmaßungen über Jakob and Christian Geißler's later almost forgotten Anfrage. ${ }^{23}$ Havu's polemical comparison does justice neither to the Finnish

\footnotetext{
22 Havu (1954).

23 Grass's first translator, Aarno Peromies, had already published a translation of Böll's Billard um halbzehn in 1960 and a translation of Anfrage in 1963.
} 
novelists she has in mind nor to the critical potential contained in Grass's novel. Die Blechtrommel may be more experimental and more modern than the works she condemns, but it is certainly not more patriotic or respectful. While Havu mentions the decision of the Bremen city fathers not to donate the prize for which Die Blechtrommel had already been selected, she certainly does not join the chorus of moral outrage which had led to that decision. On the contrary, after the polemics of the opening part of the review, Havu's own writing itself becomes rhapsodic. She describes the novel as an enthralling picaresque, a fairy tale, a history of a lost world, and she delights in its baroque contrasts between the grotesque, the tragicomic and deeply tragic images. Significantly she takes up Grass's central metaphor of the drum claiming that the novel can only really be correctly understood in musical terms, as a fantasy. It would seem that Havu, despite her conservative politics and her partisan approach to domestic Finnish literature, was capable of recognising exceptional writing when she saw it.

\section{Conclusion}

The almost universally positive tone of the reviews in the Finnish press is quite conspicuous. Some of the reviewers do sometimes appear to have been understandably shocked by some of Grass's more grotesque images, but none of them seemed outraged by the book, and all accredit the author with exceptional literary talent. Havu's misreading of the political potential of the novel is also significant in that it indicates a difference in attitude when foreign books are reviewed rather than domestic works. It would appear that works by foreign authors are more easily exempted from the kind of in-fighting that often plagues criticism of domestic works, and that phenomenon was definitely rampant in Finland in the early 196os. With the exception of Havu's review in Helsingin Sanomat, comparisons with Finnish authors were also generally value free and introduced as orientational aids for the Finnish readership.

Apart from the frequently repeated stereotype about the general heavy-handedness of the German novel, little serious attention was paid to the fact of this book being German.

In contextualising the novel most of the reviewers seem to have contented themselves with the information provided by the publisher. The frequency with which certain details recur in all the reviews is not, as one might ideally like to believe, the result of a general consensus among the readers of the novel, but probably a direct result of the way the publisher has packaged the book. None of the reviewers discussed here gives any evidence of having 
conducted background research beyond the information given on the back cover of the book. This may be why the writer is so frequently introduced as a poet and artist and why the reviewers consistently refer to his German-Polish origins.

What the reviewers all conspicuously omit to mention in this connection is the special status of Danzig between the two World Wars when the disputed city was administered under the League of Nations mandate. This piece of background information is actually quite important for an understanding of the first two thirds of the novel. One can but speculate about this omission. Either the reviewers did not consider this point of historical detail worth mentioning, or the pre-war European situation was still so fresh in people's memories in 1961 that it was self-evident. The publisher's blurb obliquely refers to the situation when it says that Grass was born in Danzig, "the cross-section of German-Polish interests", and seems to expect the readers to understand the inference, but I suspect that the specific political issues involved were not that familiar to the Finnish readership, and that the reviewers were also not particularly interested in a strongly political reading. In fact the novel is subjected by all the reviewers to a somewhat dehistoricised reading, and this again is in line with the publisher's blurb which starts with the claim that this is a "blossoming picaresque novel" and satirises people "of our time and of all ages". This is how the publisher sells the book and, to judge by the reviews, how the readers buy it.

The lack of attention to the specific historical background of the novel is quite surprising in view of the wartime experiences that Finland shared with the people of Danzig. The special international status of Danzig perished in the war, but Finland, too, lost its most cosmopolitan city, Vyborg, and had to accommodate a large influx of refugees. These were topics that post-war literature in Finland regularly dealt with. But the early reviews of Die Blechtrommel have little or nothing to say about these parallels. Little Oskar is no political analyst, but the novel is intrinsically political. It is precisely because Oskar refrains from political analysis that the novel is so successful in conveying the atmospheric tensions leading up to World War II and the subsequent mood of the incipient economic miracle. But rather than commenting on what Oskar sees, the early Finnish reviewers preferred to concentrate on what he is.

Thus the novel's topical view of the present and the recent past goes almost unnoticed. Instead the early reviewers almost unanimously emphasise its exotic aspects, the strange qualities of the protagonist and the insights the novel offers into universal human nature. In this respect it is significant that the evaluative judgments of the critics were generally implicit in the comparisons drawn to works generally accepted as belonging to the canon of "world 
literature". By accepting and thus enhancing the publisher's strategy of marketing the novel as a picaresque in the tradition of Don Quixote or Grimmelshausen's Simplicissimus, the Finnish critics lift the novel out of the realm of social debate in which works of their own national literature are discussed. It seems that in the context of the national literary space, to employ a term of Pascale Casanova $^{24}$, the translated work is treated with the respect due to a guest rather than being exposed to the full pressure of public criticism.

\section{Bibliography}

A. I.-la, "Hartaasti, herkeämättä, kunhan ei pelkää kertaamista," in Suomen Sosiaalidemokraatti, June 11, 1961.

Casanova, P., The World Republic of Letters (Cambridge MA/London, 2004).

Grass, G., Peltirumpu [suomentanut Aarno Peromies], (Helsinki, 1961).

Grass, G., Peltirumpu [suomentanut Oili Suominen; jälkisana: Jukka Koskelainen], (Helsinki, 1961).

Havu, T., "Väinö Linna: Tuntematon sotilas", in Helsingin Sanomat, December 19, 1954, 16.

Havu, T., "Fantasia peltirummulle," in Helsingin Sanomat, November 16, 1961.

'Kirjamies', “Huikea veijariromaani," in Vaasa, July 15, 1961.

Klinge, M., "Finnland - Zufall oder Plan?" in J. Hecker-Stampehl, Henningsen, B., Mertens, A., Schröder, S. (eds.), 1809 und die Folgen (Berlin, 2011), 15- 21.

Manninen, Kerttu, "Käännösromaaneja vuodelta 1961," in Kirjastolehti 2/1962, 30-35.

Parry, C., "Deutsch-finnische Literaturbeziehungen gestern und heute," in J. HeckerStampehl, Henningsen, B., Mertens, A., Schröder, S. (eds.), 1809 und die Folgen (Berlin, 2011), 287-300.

Polkunen, M., "Oskarin Aika," in Uusi Suomi, May 21, 1961.

R-o S-lä, "Saksalainen lasisuurmajaihme," in Aamulehti, June 11, 1961.

Saarikoski, P., "Cinerama," in Parnasso 5 (1961), 257-258.

Seppä, "Oskarin kokoinen," in Kaleva, June 23, 1961.

Tarkka, P., Paavo Rintalan saarna ja seurakunta. Kirjallisuussosiologinen kuvaus Paavo Rintalan tuotannosta, suomalaisen kirjasodan rintamista ja kirjallisuuden asemasta kulttuurin murroksessa (Helsinki 1966).

Wilfinger, R., Die finnische Rezeption der Blechtrommel (unpublished Masters' thesis Jyvväskylä, 1993).

24 Casanova $(2004) 3$. 